\title{
Oaks as Beacons of Hope for Threatened Mixed Forests in Central Europe
}

\author{
Hilke Schroeder ${ }^{1 *}$, Tetyana Nosenko ${ }^{2}$, Andrea Ghirardo ${ }^{2}$, Matthias Fladung ${ }^{1}$, \\ Jörg-Peter Schnitzler ${ }^{2}$ and Birgit Kersten ${ }^{1}$ \\ ${ }^{1}$ Thünen-Institute of Forest Genetics, Grosshansdorf, Germany, ${ }^{2}$ Research Unit Environmental Simulation, Institute of \\ Biochemical Plant Pathology, Helmholtz Zentrum München, Neuherberg, Germany
}

Keywords: Quercus, resistance, tolerance, tree-insect interaction, genomics, phenotype, genotype

\section{INTRODUCTION}

Climate change has a severe impact on forest ecosystems (Seidl et al., 2017). Adaptation of trees to the rapidly changing regional climate is hampered by their longevity and late reproductive age. Therefore, the increases in frequency, duration and intensity of drought episodes, heat waves and heavy rainfall events (Spinoni et al., 2018; Hari et al., 2020) threaten many tree species of European forests. As a result, environmentally stressed trees will become vulnerable to pronounced damage from herbivorous insects and pathogens. Thus, the damage caused by insects increases the vulnerability of forests to fungal infections and secondary pests (Meyer et al., 2015), and conversely, fungal infections can promote the development of herbivores (Eberl et al., 2020). Both together then contribute to the higher overall vulnerability of forests.

With regional shifts in weather conditions and climate zones in Europe, complex combinations of abiotic and biotic stresses will likely occur. The quick succession of abiotic and biotic stresses can further worsen forest damage. A quantification of the vulnerability of European forests to windthrows (40\% of losses), fires (34\%), and insect outbreaks (26\%) during the period 1979-2018 revealed that about 33.4 billion tons of forest biomass were seriously affected by these disturbances (Forzieri et al., 2021). There is a clear trend toward higher overall forest vulnerability driven by a warming-induced reduction in plant defenses against insect outbreaks, especially at high latitudes.

If forests fail to adapt to climate changes, there will be manifold consequences for the ecosystem function and services, productivity, biodiversity, and negative feedbacks to climate (Ammer, 2019).

\section{IMPORTANCE OF EUROPEAN OAKS AND HISTORY OF OAK DECLINE}

The two predominant oak species in Central Europe, English oak (Quercus robur L.) and sessile oak (Q. petraea Matt.) are two of about 50 tree species growing in European forests. Together their share of about $10 \%$ of the stands makes oaks the second most common deciduous tree species in Europe after beech (Bolte et al., 2007; BMEL., 2014). Among tree species native to Europe, oaks have the highest species diversity at all trophic levels. More than a thousand animal species (including insects, birds, small mammals) live on and with oaks (ProQuercus). Economically, oak wood has a special importance due to its high strength and resistance. It is used as construction timber, as well as processed into barrels, railroad sleepers, furniture, parquet, and veneers. 
In Central Europe, frequent insect outbreaks are believed to be one of the causes of the oak decline observed in the last century (Gasow, 1925; Thomas et al., 2002; Denman and Webber, 2009). The first important oak dieback was observed already in 19111920 and later in the 1980s; oaks of all age groups died at a rate of 2-5 trees per hectare and per year due to insect defoliation often co-occurring with drought events (Hartmann and Blank, 1992; Denman and Webber, 2009).

The decline of European oaks can be explained by changing climatic conditions and their consequences like heavy rains, local floods, and pests (Keča et al., 2016). Root pathogens from the genus Phytophthora DeBary especially benefit from wet soils following heavy rain events. Phytophthora threats have been observed in oaks in North America and Europe since the 1990s with various impact on different species (Sturrock et al., 2011). For Q. robur, soil acidity was recognized as the main factor for enhanced susceptibility to Phytophthora infections (Jönsson et al., 2003).

A decline in growth rate was observed in the second or third year after drought events when comparing tree-ring series in Q. robur and Q. petraea stems at three different sites (Perkins et al., 2018). Being a ring-porous tree species, oaks are most likely categorized as anisohydric species which strive to regulate stomatal conductance to keep photosynthetic processes alive, even during drought periods. However, anisohydric traits may lead to a longer drought memory due to high investments to sustain photosynthetic activity, thus leading to a hangover of drought effects (Perkins et al., 2018).

Even more herbivorous insect species from Southern and Eastern Europe will likely migrate into central European forests (Sturrock et al., 2011; Pureswaran et al., 2018), as it has been observed for the oak processionary moth Thaumetopoea processionea L. (Bolte et al., 2009). Owing to climate change, also native species, such as the oak splendor beetle Agrilus biguttatus Fabr., increase their infestation ability and are predicted to cause more serious damage (Bolte et al., 2009; Sanders et al., 2013).

\section{ADVANTAGES OF EUROPEAN OAKS (QUERCUS SPP.)}

Temperature increase during the last decades caused changes in the abundance of broadleaved species in European forests, e.g., beech (Fagus sylvatica L.) forests have declined in several regions of Central Europe (Denmark: Huang et al., 2017; Germany: Dulamsuren et al., 2017; Austria: Corcobado et al., 2020). This decline of beech is only marginally caused by outbreaks of insects. This is not unexpected because compared to oaks, beech suffers only from a low number of insect pests as e.g., the splendor beetle Agrilus viridis L. (Bolte et al., 2009). A major threat for beeches are Phytophthora infections which are observed since the 1930s. In combination with drought periods and heatwaves since 2003, the beech decline has increased dramatically in comparison with oak (Corcobado et al., 2020).

A study covering 50 years of phenological data showed that oak and beech follow different phenological strategies with oaks having the better adaptation capacity to climate change due to a higher phenological plasticity (Wenden et al., 2019). Furthermore, oaks have the possibility to maintain their hydraulic status during dry summers due to their extensive root system reaching deep soil layers (Zapater et al., 2011; Scharnweber et al., 2013). Beech reacts with phenological maladaptation to changes in temperature and water regime, slightly compensated by within-population genetic diversity (Frank et al., 2017). Beech is threatened especially in its warmer distribution areas with potential reduction of its vitality (Wenden et al., 2019). Under future climate projection, $10-16 \%$ growth rate decline is predicted for F. sylvatica by 2100 , while an increase of $12 \%$ growth rate is expected for Q. robur (Huang et al., 2017). Therefore, in climatically warmer areas, where beech is likely to reach its limits (Kramer et al., 2010), oak may prevail over beech because it is already adapted to the warmer climate (Delb, 2012; Cuervo-Alarcon et al., 2021). In more northern regions, on the other hand, a successful strategy should be to support oak and beech to maintain resilient mixed forests that help mitigate the effects of climate change because an adequate species mix can even lead to increased productivity (Pretzsch et al., 2013).

Increasing spring temperatures enhance seed production and dispersal in temperate oaks (Caignard et al., 2017). A higher reproduction success of temperate oaks is associated with improved fitness. Furthermore, the extension of the growing season leads to an increase in vegetative growth of $Q$. petraea and Q. robur (Saxe et al., 2001; Caignard et al., 2017). So, both higher seed production and vegetative growth seem possible in temperate oaks during climate change. A comparative analysis of genetic diversity in adult and offspring generations in beech and oak populations coexisting in a naturally established oldgrowth forest stand, revealed that adult generations of both species exhibited high levels of genetic diversity (He: 0.657 for beech; 0.821 for oak; depending on the sets of selected genetic markers) (Sandurska et al., 2017).

The high genetic diversity of oaks and beeches will facilitate adaptation to climate change. In addition, there is the adaptive potential in oaks resulting from introgression (hybridization of e.g., Q. petraea and Q. robur in overlapping habitats; Kremer and Hipp, 2020). It is increasingly recognized that hybrids play an important role in evolutionary processes. Thus, natural or man-made oak hybrids together with successful oak breeding programs and grafting of superior individuals may lead to novel traits that give oak decisive advantages in evolutionary processes, facilitating gene flow.

Due to massive anthropogenic activities in the past, natural regeneration of European tree species is mostly developed from remaining local stocks (Bradshaw, 2004). In our opinion, this may result in lower genetic diversity for naturally regenerating tree species as beech compared to bred and out-planted tree species as temperate oaks.

\section{GENOMICS AND MOLECULAR MARKERS OF CLIMATE-CHANGE RELEVANT TRAITS}

In oaks, phenotypic traits of particular importance include among others drought tolerance, resistance to insects and 


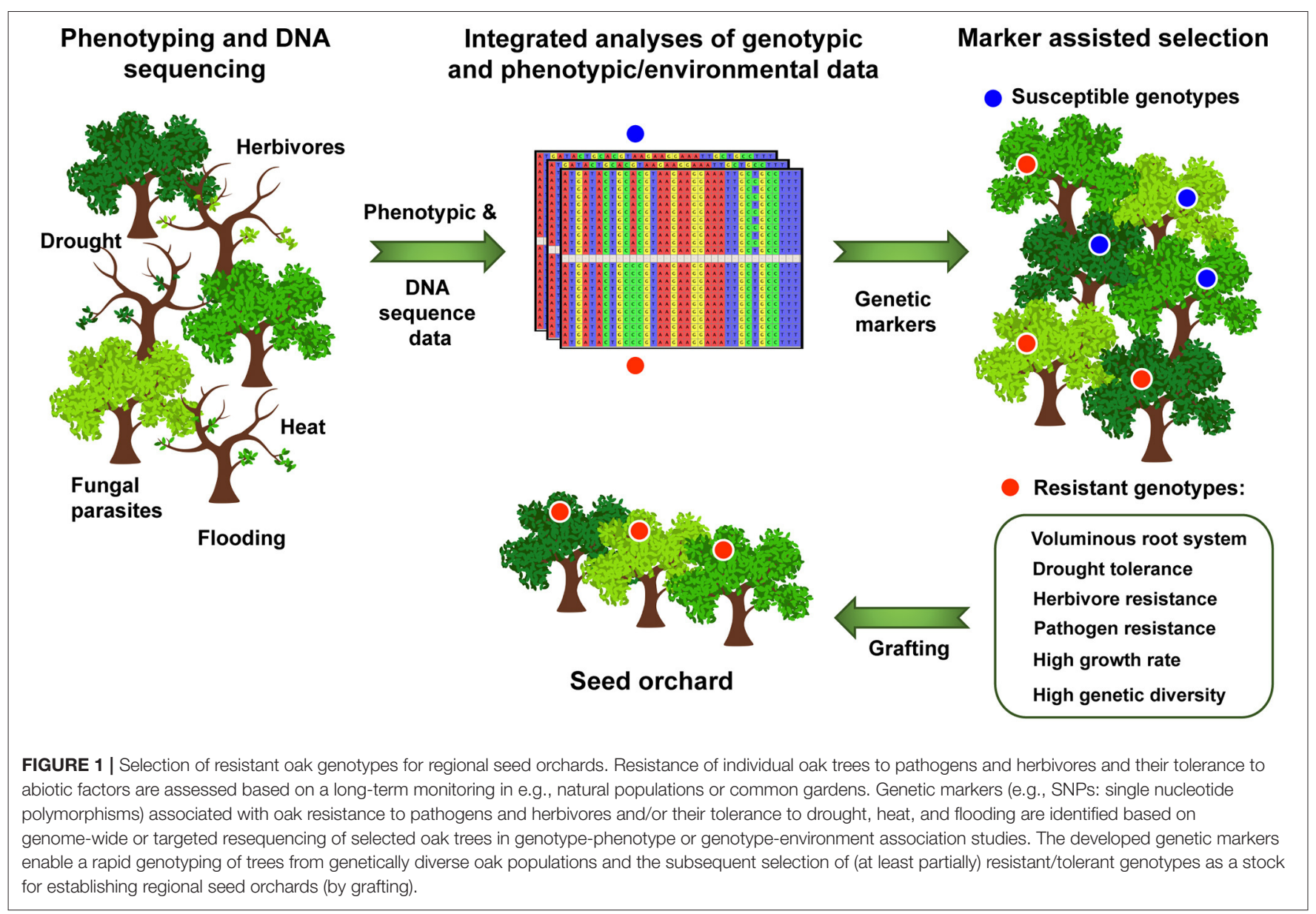

pathogens, and growth-related traits. These traits are expected to be influenced multi-factorially and inherited poly-genetically. The increasing availability of reference genomes for different oak species is the prerequisite to identify the underlying genes/genomic loci and develop diagnostic genetic markers for breeding programs (Badenes et al., 2016). First success is shown, for example, in the quantitative trait loci (QTL) study which identified two regions associated with Erysiphe alphitoides infection in the Q. robur genome (Bartholomé et al., 2020).

In addition to QTL studies, genome-wide association studies (GWAS) in natural populations, common gardens, or other experimental settings (e.g., McKown et al., 2018) provide new insights (Figure 1). Challenging in these studies is the lack of efficient methods for tree phenotyping (Dungey et al., 2018) and the modeling of complex genomic traits. Multitrait GWAS approaches, as applied to Populus trichocarpa (Chhetri et al., 2019), may help to uncover potentially pleiotropic effects of individual genes in Quercus, especially when analyzing climate-relevant traits.

Analyzing genome-wide associations between single nucleotide polymorphisms and environmental/climate variables may be the key to identify adaptive genetic markers in Quercus (Figure 1). Alternatively, genomic selection approaches may help identifying genotypes with the climate change-relevant traits and their genotypic plasticity. Using a large-scale common garden experiment in combination with genome sequencing and calculation of genomic estimated breeding values, Browne et al. (2019) identified several Q. lobata genotypes that grow relatively fast under higher temperatures. These genotypes, which are presumably pre-adapted to future climates, were proposed by the authors to serve as seed sources for assisted gene flow programs.

An alternative approach is developing molecular markers for important traits in the genus Quercus based on transcriptome, proteome, and metabolome data. Examples include omics studies on signaling pathways induced in $Q$. robur by herbivory (e.g., Ghirardo et al., 2012; Kersten et al., 2013), which play a central role in plant defense against herbivorous insects (summarized in Erb and Reymond, 2019). Another example is cross-species comparative transcriptomics analysis of $Q$. robur, Q. pubescens, and the evergreen $Q$. ilex $\mathrm{L}$. to reveal drought-related molecular patterns (Madritsch et al., 2019).

Once developed, molecular markers can be used to identify and select (at least partially) resistant/tolerant oak ecotypes/genotypes using marker-assisted selection (Figure 1). Among several modern strategies (Cortés et al., 2020), the use of molecular markers is one of the most promising 
strategies to evaluate and breed oak adaptation to changing climatic conditions.

\section{CONCLUSIONS}

We need to prepare our forests for the impending climate change consequences through silvicultural and breeding measures to mitigate forest vulnerability. Ecosystems should increment genotypes that are characterized by an increased tolerance to various biotic and abiotic stresses. Overall, complex consideration of tree tolerance to different stressors is crucial for assessing their adaptive capacity to climate change.

Particularly in the more northern European forests, supporting oaks and beeches will help maintain resilient mixed forests to mitigate climate change effects on forest ecosystems. The asynchrony of drought responses between these tree species could stabilize productivity in forests where both species occur (Rubio-Cuadrado et al., 2018). Q. robur, Q. petraea, and related hybrids may play a crucial role in helping forests adapting to climate change. Therefore, silvicultural approaches for the climate-smart forestry should take advantage of these climate-stable properties of oaks by establishing the required light regime for this species to increase its proportion in European forests (Perkins et al., 2018). Future development and application of genetic markers will aid in assessing the

\section{REFERENCES}

Ammer, C. (2019). Diversity and forest productivity in a changing climate. New Phytol. 221, 50-66. doi: 10.1111/nph.15263

Badenes, M. L., Marti, A. F. I., Rios, G., and Rubio-Cabetas, M. J. (2016). Application of genomic technologies to the breeding of trees. Front. Genet. 7:198. doi: 10.3389/fgene.2016.00198

Bartholomé, J., Brachi, B., Marçais, B., Mougou-Hamdane, A., Bodénés, C., Plomion, C., et al. (2020). The genetics of exapted resistance to two exotic pathogens in pedunculate oak. New Phytol. 226, 1088-1103. doi: 10.1111/nph. 16319

BMEL. (2014). Der Wald in Deutschland. Ausgewählte Ergebnisse der Dritten Bundeswaldinventur. Berlin: BMEL.

Bolte, A., Ammer, C., Löf, M., Madsen, P., Nabuurs, G. J., Schall, P., et al. (2009). Adaptive forest management in central Europe: climate change impacts, strategies and integrative concept. Scand. J. Forest Res. 24, 473-482. doi: 10.1080/02827580903418224

Bolte, A., Czajkowski, T., and Kompa, T. (2007). The north-eastern distribution range of European beech - a review. Forestry 80, 413-429. doi: 10.1093/forestry/cpm028

Bradshaw, R. H. W. (2004). Past anthropogenic influence on European forests and some possible genetic consequences. Forest Ecol. Manag. 197, 203-212. doi: 10.1016/j.foreco.2004.05.025

Browne, L., Wright, J. W., Fitz-Gibbon, S., Gugger, P. F., and Sork,. V. L. (2019). Adaptational lag to temperature in valley oak (Quercus lobata) can be mitigated by genome-informed assisted gene flow. Proc. Natl. Acad. Sci. U.S.A. 116, 25179-25185. doi: 10.1073/pnas.19087 71116

Caignard, T., Kremer, A., Firmat, C., Nicolas, M., Venner, S., and Delzon, S. (2017). Increasing spring temperatures favor oak seed production in temperate areas. Sci. Rep. 7:8555. doi: 10.1038/s41598-017-0 9172-7

Chhetri, H. B., Macaya-Sanz, D., Kainer, D., Biswal, A. K., Evans, L. M., Chen, J. G., et al. (2019). Multitrait genome-wide association analysis of adaptability and resilience of planted oak material in the face of the proposed shifts of the climate zones and in selecting material that can withstand the multiple challenges of climate change for the forest of the future.

\section{AUTHOR CONTRIBUTIONS}

HS and BK wrote the first draft of the manuscript. TN developed and designed the figure. All authors developed the concept, structure of the manuscript, accomplished, checked the first version, and read and approved the submitted version.

\section{FUNDING}

The project leading to this paper was financed by the Fachagentur Nachwachsende Rohstoffe e. V. (FNR) in the programme Waldklimafond (28W-B-4-113-01/2) funded by Federal Ministry of Food and Agriculture and Federal Ministry for Environment, Nature Conservation and Nuclear Safety, Germany.

\section{ACKNOWLEDGMENTS}

We like to thank all technical assistants, gardeners, and colleagues who contribute to our work over the last years.
Populus trichocarpa identifies key polymorphisms controlling morphological and physiological traits. New Phytol. 223, 293-309. doi: 10.1111/nph.15777

Corcobado, T., Cech, T. L., Brandstetter, M., Daxer, A., Hüttler, C., Kudlácek, T., et al. (2020). Decline of European Beech in Austria: involvement of Phytophthora spp. and contributing biotic and abiotic factors. Forests 11:895. doi: 10.3390/f11080895

Cortés, A. J., Restrepo-Montoya, M., and Bedoya-Canas, L. E. (2020). Modern strategies to assess and breed forest tree adaptation to changing climate. Front. Plant Sci. 11:583323. doi: 10.3389/fpls.2020.583323

Cuervo-Alarcon, L., Arend, M., Müller, M., Sperisen, C., Finkeldey, R., and Krutovsky, K. V. (2021). A candidate gene association analysis identifes SNPs potentially involved in drought tolerance in European beech (Fagus sylvatica L.). Sci. Rep. 11:2386. doi: 10.1038/s41598-021-81594-w

Delb, H. (2012). Eichenschädlinge im Klimawandel in Südwestdeutschland. FVAEinblick 2, 11-14.

Denman, S., and Webber, J. (2009). Oak declines: new definitions and new episodes in Britain. Q. J. Forest 103, 285-290.

Dulamsuren, C., Hauck, M., Kopp, G., Ruff, M., and Leuschner, C. (2017). European beech responds to climate change with growth decline at lower, and growth increase at higher elevations in the center of its distribution range (SW Germany). Trees 31, 673-686. doi: 10.1007/s00468-016-1499-x

Dungey, H. S., Dash, J. P., Pont, D., Clinton, P. W., Watt, M. S., and Telfer, E. J. (2018). Phenotyping whole forests will help to track genetic performance. Trends Plant Sci. 23, 854-864. doi: 10.1016/j.tplants.2018.08.005

Eberl, F., Fernandez de Bobadilla, M., Reichelt, M., Hammerbacher, A., Gershenzon, J., and Unsicker, S. B. (2020). Herbivory meets fungivory: insect herbivores feed on plant pathogenic fungi for their own benefit. Ecol. Lett. 23, 1073-1084. doi: 10.1111/ele.13506

Erb, M., and Reymond, P. (2019). Molecular interactions between plants and insect herbivores. Annu. Rev. Plant Biol. 70, 527-557. doi: 10.1146/annurev-arplant-050718-095910

Forzieri, G., Girardello, M., Ceccherini, G., Spinoni, J., Feyen, L., Hartmann, H., et al. (2021). Emergent vulnerability to climate-driven disturbances in European forests. Nat. Commun. 12:1081. doi: 10.1038/s41467-021-21399-7 
Frank, A., Pluess, A. R., Howe, G. T., Sperisen, C., and Heiri, C. (2017). Quantitative genetic differentiation and phenotypic plasticity of European beech in a heterogeneous landscape: indications for past climate adaptation. Perspect. Plant Ecol. 26, 1-13. doi: 10.1016/j.ppees.2017.02.001

Gasow, H. (1925). Der grüne Eichenwickler (Tortrix viridana Linne) als Forstschädling. Arb. Biol. Reichsanst. 12, 355-508.

Ghirardo, A., Heller, W., Fladung, M., Schnitzler, J. P., and Schroeder, H. (2012). Function of defensive volatiles in pedunculate oak (Quercus robur) is tricked by the moth Tortrix viridana. Plant Cell Environ. 35, 2192-2207. doi: 10.1111/j.1365-3040.2012.02545.x

Hari, V., Rakovec, O., Markonis, Y., Hanel, M., and Kumar, R. (2020). Increased future occurrences of the exceptional 2018-2019 Central European drought under global warming. Sci. Rep. 10:12207. doi: 10.1038/s41598-020-68872-9

Hartmann, G., and Blank, R. (1992). Winterfrost, Kahlfraß und Prachtkäferbefall als Faktoren im Ursachenkomplex des Eichensterbens in Norddeutschland. Forst. Holz. 15, 443-452.

Huang, W., Fonti, P., Larsen, J. B., Ræbild, A., Callesen, I., Pedersen, N. B., et al. (2017). Projecting tree-growth responses into future climate: a study case from a Danish-wide common garden. Agric. For. Meteorol. 247, 240-251. doi: 10.1016/j.agrformet.2017.07.016

Jönsson, U., Jung, T., Rosengren, U., Nihlgård, B., and Sonesson, K. (2003). Pathogenicity of Swedish isolates of Phytophthora quercina to Quercus robur in two different soils. New Phytol. 158, 355-364. doi: 10.1046/j.1469-8137.2003.00734.x

Keča, N., Koufakis, I., Dietershagen, J., Nowakowska, J. A., and Oszako, T. (2016). European oak decline phenomenon in relation to climatic changes. Folia Forest. Polon. A 58, 170-177. doi: 10.1515/ffp-2016-0019

Kersten, B., Ghirardo, A., Schnitzler, J. P., Kanawati, B., Schmitt-Kopplin, P., Fladung, M., et al. (2013). Integrated transcriptomics and metabolomics decipher differences in the resistance of pedunculate oak to the herbivore Tortrix viridana L. BMC Genom. 14:737. doi: 10.1186/1471-2164-14-737

Kramer, K., Degen, B., Buschbom, J., Hickler, T., Thuiller, W., Sykes, M. T., et al. (2010). Modelling exploration of the future of European beech (Fagus sylvatica L.) under climate change-Range, abundance, genetic diversity and adaptive response. Forest Ecol. Manag. 259, 2213-2222. doi: 10.1016/j.foreco.2009.12.023

Kremer, A., and Hipp, A. L. (2020). Oaks: An evolutionary success story. New Phytol. 226, 987-1011. doi: 10.1111/nph.16274

Madritsch, S., Wischnitzki, E., Kotrade, P., Ashoub, A., Burg, A., Fluch, S., et al. (2019). Elucidating drought stress tolerance in European oaks through crossspecies transcriptomics. G3 9, 3181-3199. doi: 10.1534/g3.119.400456

McKown, A. D., Klápště, J., Guy, R. D., El-Kassaby, Y. A., and Mansfield, S. D. (2018). Ecological genomics of variation in bud-break phenology and mechanisms of response to climate warming in Populus trichocarpa. New Phytol. 220, 300-316. doi: 10.1111/nph.15273

Meyer, J. B., Gallien, L., and Prospero, S. (2015). Interaction between two invasive organisms on the European chestnut: does the chestnut blight fungus benefit from the presence of the gall wasp? FEMS Microbiol. Ecol. 91:fiv122. doi: $10.1093 /$ femsec/fiv122

Perkins, D., Uhl, E., Biber, P., du Toit, B., Carraro, V., Rötzer, T., et al. (2018). Impact of climate trends and drought events on the growth of oaks (Quercus robur L. and Quercus petraea (Matt.) Liebl.) within and beyond their natural range. Forests 9:108. doi: 10.3390/f9030108

Pretzsch, H., Bielak, K., Block, J., Bruchwald, A., Dieler, J., Ehrhart, H. P., et al. (2013). Productivity of mixed versus pure stands of oak (Quercus petraea (M att.) L iebl. and Quercus robur L.) and European beech (Fagus sylvatica L.) along an ecological gradient. Eur. J. For. Res. 132, 263-280. doi: 10.1007/s10342-012-0673-y

ProQuercus. Der Naturwert von eichenreichen Wäldern. Available online at: https://www.proquercus.org/willkommen/die-eiche/biodiversit\%C3\%A4t/ (accessed May 27, 2021).

Pureswaran, D. S., Roques, A., and Battisti, A. (2018). Forest insects and climate change. Curr. Forestry Rep. 4, 35-50. doi: 10.1007/s40725-018-0075-6

Rubio-Cuadrado, A., Camarero, J.J., R\}'1o, M., Sánchez-González, M., RuizPeinado, R., Bravo-Oviedo, A., et al. (2018). Drought modifies tree competitiveness in an oak-beech temperate forest. For. Ecol. Manag. 429, 7-17. doi: 10.1016/j.foreco.2018.06.035

Sanders, T. G. M., Pitman, R., and Broadmeadow, M. S. J. (2013). Speciesspecific climate response of oaks (Quercus spp.) under identical environmental conditions. iForest 7, 61-69. doi: 10.3832/ifor0911-007

Sandurska, E., Ulaszewski, B., and Burczyk, J. (2017). Genetic insights into ecological succession from oak- (Quercus robur L.) to beech- (Fagus sylvatica L.) dominated forest stands. Acta Biol. Cracoviens. Ser. Bot. 59/1, 23-33. doi: 10.1515/abcsb-2017-0002

Saxe, H., Cannell, M. G. R., Johnson, Ø., Ryan, M. G., and Vourlitis, G. (2001). Tree and forest functioning in response to global warming. New Phytol. 149, 369-400. doi: 10.1046/j.1469-8137.2001.00057.x

Scharnweber, T., Manthey, M., and Wilmking, M. (2013). Differential radial growth patterns between beech (Fagus sylvatica L.) and oak (Quercus robur L.) on periodically waterlogged soils. Tree Physiol. 33, 425-437. doi: 10.1093/treephys/tpt020

Seidl, R., Thom, D., Kautz, M., Martin-Benito, D., Peltoniemi, M., Vacchiano, G., et al. (2017). Forest disturbances under climate change. Nat. Clim. Change 7, 394-402. doi: 10.1038/nclimate3303

Spinoni, J., Vogt, J. V., Naumann, G., Barbosa, P., and Dosio, A. (2018). Will drought events become more frequent and severe in Europe? Int. J. Climatol. 38, 1718-1736. doi: 10.1002/joc.5291

Sturrock, R. N., Frankel, S. J., Brown, A. V., Hennon, P. E., and Kliejunas, J. T., Lewis, K. J., et al. (2011). Climate change and forest diseases. Plant Pathol. 60, 133-149. doi: 10.1111/j.1365-3059.2010.02406.x

Thomas, F. M., Blank, R., and Hartmann, G. (2002). Abiotic and biotic factors and their interactions as causes of oak decline in Central Europe. For. Pathol. 32, 277-307. doi: 10.1046/j.1439-0329.2002.00291.x

Wenden, B., Mariadassou, M., Chmielewski, F. M., and Vitasse, Y. (2019). Shifts in the temperature-sensitive periods for spring phenology in European beech and pedunculate oak clones across latitudes and over recent decades. Glob. Change Biol. 26, 1808-1819. doi: 10.1111/gcb.14918

Zapater, M., Hossann, C., Bréda, N., Bréchet, C., Bonal, D., and Granier, A. (2011). Evidence of hydraulic lift in a young beech and oak mixed forest using $18 \mathrm{O}$ soil water labelling. Trees 25, 885-894. doi: 10.1007/s00468-011-0563-9

Conflict of Interest: The authors declare that the research was conducted in the absence of any commercial or financial relationships that could be construed as a potential conflict of interest.

Copyright (C) 2021 Schroeder, Nosenko, Ghirardo, Fladung, Schnitzler and Kersten. This is an open-access article distributed under the terms of the Creative Commons Attribution License (CC BY). The use, distribution or reproduction in other forums is permitted, provided the original author(s) and the copyright owner(s) are credited and that the original publication in this journal is cited, in accordance with accepted academic practice. No use, distribution or reproduction is permitted which does not comply with these terms. 